\title{
A Non-luminescent Strain of Xenorhabdus luminescens (Enterobacteriaceae)
}

\author{
By R. J. AKHURST*† AND N. E. BOEMARE $\ddagger$ \\ Division of Entomology, CSIRO, Stowell Avenue, Hobart, Tasmania 7000, Australia
}

(Received 18 December 1985; revised 4 March 1986)

The first case of a non-luminescent symbiont of a Heterorhabditis sp. is reported. The bacterium, isolated from a previously unknown species of Heterorhabditis, was identified as a biovar of Xenorhabdus luminescens. Ultrastructural study of the bacterium revealed membranous and crystalline inclusions comparable with those of luminescent strains of $X$. luminescens.

\section{INTRODUCTION}

Heterorhabditis species, insect pathogenic nematodes, are mutualistically associated with Xenorhabdus luminescens, a bioluminescent bacterium (Khan \& Brooks, 1977; Poinar et al., 1977; Thomas \& Poinar, 1983; Akhurst, 1983). The free-living, infective-stage nematode, which does not feed, carries its bacterial symbiont monoxenically within its intestine. After penetrating an insect host the nematode invades the haemocoel where it releases the bacterium. The bacterium proliferates and establishes favourable conditions for nematode reproduction by providing nutrients and inhibiting the growth of many foreign micro-organisms (Poinar \& Thomas, 1966; Akhurst, 1982a). After two or more weeks, up to $10^{6}$ nematodes per $\mathrm{g}$ of insect host are produced and emigrate from the cadaver, carrying their bacterial symbiont to new hosts.

Xenorhabdus species occur in two forms (Akhurst, 1980). The primary form is carried within the infective-stage nematode and is unstable in vitro and occasionally in vivo, producing the secondary form. The most important differences between the two forms are the primary form's better ability to provide nutrient for the nematodes (Akhurst, 1980) and its production of antimicrobial agents (Akhurst, 1982a). The two forms also vary in several biochemical and colonial characteristics and, in $X$. luminescens, in the lesser degree of bioluminescence in the secondary form (Akhurst, 1980).

For the first time, a strain of Heterorhabditis (of a previously unknown species) was found associated with a non-luminescent bacterium (R. A. Bedding and co-workers, unpublished observations). This bacterium was studied to determine whether it was $X$. luminescens and whether it contained the lattice-like inclusions ('structures en treillis') that Boemare et al. (1983) described and suggested were photosomes.

\section{METHODS}

Nematodes. Heterorhabditis sp. strain Q614 was isolated from soil taken from Bundaberg, Queensland, Australia, by the method of Bedding \& Akhurst (1975). Heterorhabditis heliothidis was obtained from Dr W. Wouts, Department of Scientific and Industrial Research, Auckland, New Zealand.

Bacteria. Bacterial isolates $\mathrm{Cl}$ and Q614 were obtained from $H$. heliothidis and Heterorhabditis sp. strain Q614, respectively. Primary-form bacteria were isolated by macerating surface-sterilized infective-stage nematodes (Akhurst, 1980). Secondary-form bacteria were isolated from monoxenic in vitro cultures established with surfacesterilized infective-stage nematodes and maintained on the medium of Bedding (1984).

† Present address: Division of Entomology, CSIRO, GPO Box 1700, Canberra, ACT 2601, Australia. ‡Present address: Laboratoire de Pathologie Comparée, Université des Sciences, Montpellier, France. 
Bioluminescence. This was assessed quantitatively by observing, in a darkroom for $10 \mathrm{~min}$, cultures on nutrient $\operatorname{agar}(\mathrm{NA})$, YS agar $\left(0.5 \mathrm{~g} \mathrm{NH}_{4} \mathrm{H}_{2} \mathrm{PO}_{4}, 0.5 \mathrm{~g} \mathrm{~K}_{2} \mathrm{HPO}_{4}, 0.2 \mathrm{~g} \mathrm{MgSO}_{4} .7 \mathrm{H}_{2} \mathrm{O}, 5 \mathrm{~g} \mathrm{NaCl}, 5 \mathrm{~g}\right.$ yeast extract, $12 \mathrm{~g}$ agar in 11 water; Dye, 1968) and $\mathrm{X}$ agar (4 $\mathrm{g}$ Bacto-peptone, $5 \mathrm{~g} \mathrm{NaCl}, 4 \mathrm{~g}$ glucose, $12 \mathrm{~g}$ agar in 11 water; adjusted with $1 \mathrm{M}$-Tris to pH 7.4; Götz et al., 1981) up to $5 \mathrm{~d}$ after inoculation.

Bacteria from $3 \mathrm{~d}$ NA cultures were suspended in distilled water and the optical density was measured by light scattering in an EEL nephelometer. Luminescence of the suspensions was assessed in a scintillation counter (Packard Prias model PL/PLD, tritium setting), which took a series of readings during a 1 min period and gave the results as mean c.p.m. \pm SD.

Taxonomy. Bacteria from $24 \mathrm{~h}$ YS broth (Dye, 1968) cultures grown at $28^{\circ} \mathrm{C}$ were used for the Gram stain and were assessed for motility by microscopic examination.

All biochemical tests were done at $28^{\circ} \mathrm{C}$. Most tests were done by the same methods as Akhurst (1983). The exceptions follow. Casein hydrolysis was tested on milk agar prepared with equal volumes of skim milk and double strength NA; the agar was flooded with mercuric chloride reagent (Frazier, 1926) after $7 \mathrm{~d}$ to confirm that clearing was due to proteolysis. Lipase activity was assessed on Sierra's (1957) medium with $0.5 \%(\mathrm{v} / \mathrm{v})$ Tween 80 . The test for phenylalanine deaminase was done after $5 \mathrm{~d}$ with ferric perchloride reagent ( $10 \%$ in aqueous solution).

Utilization of organic acids was tested in OY agar [YS agar with the yeast extract reduced to $0.08 \%(w / v)+$ $0.0016 \%(\mathrm{w} / \mathrm{v})$ bromothymol blue $+0.2 \%(\mathrm{w} / \mathrm{v})$ salt of the organic acid; Dye, 1968]. Acidification of carbohydrates was assessed over $10 \mathrm{~d}$ with API $50 \mathrm{CH}$ strips (API system) inoculated with the bacteria suspended in API 50CHE medium. Acidification of gluconate, glycerol, inositol, melezitose, ribose, salicin and trehalose, and of D-xylose was also tested in peptone water with $1 \%(\mathrm{w} / \mathrm{v})$ of the carbon source and using bromocresol purple as indicator.

Antimicrobial activity was tested by the method of Akhurst (1982a), using Micrococcus luteus as the indicator organism. Pathogenicity was tested by injection into the haemocoel of Galleria mellonella larvae of 100 cells (total cell count) suspended in Ringer's solution. Mortality was recorded after $3 \mathrm{~d}$ at $23^{\circ} \mathrm{C}$.

Ultrastructure. Cultures ( 3 to $4 \mathrm{~d}$ ) were fixed in situ with $2.5 \%(\mathrm{v} / \mathrm{v})$ glutaraldehyde in $0.1 \mathrm{M}$-cacodylate buffer, $\mathrm{pH}$ $7 \cdot 4$, with $0.015 \%(\mathrm{v} / \mathrm{v}) \mathrm{CaCl}_{2}$ and post-fixed in $1 \%$ osmium tetroxide. Samples were washed in $2 \%$ sodium acetate, stained in $2 \%(\mathrm{w} / \mathrm{v})$ aqueous uranyl acetate and dehydrated by passage through an acetone series before being embedded in Spurr's resin. Thin sections (70 nm thick) were stained with uranyl acetate (saturated in $1: 170 \%$, $\mathrm{v} / \mathrm{v}$, ethanol/methanol) and lead citrate (Reynolds, 1963) and examined in a Jeol JEM-100C electron microscope.

\section{RESULTS}

Bioluminescence. Bioluminescence was clearly visible in 2-5 d cultures of the primary and secondary forms of the symbiont of $H$. heliothidis (strain $\mathrm{C1}$ ) within $10 \mathrm{~min}$ and appeared strongest on $3 \mathrm{~d}$ NA cultures. The primary-form culture was more strongly bioluminescent than the secondary form. No bioluminescence was evident from cultures of either form of strain Q614 of any age on any of the media.

Measurements made by scintillation counter indicated that both forms of strain $\mathrm{Cl}$ were bioluminescent whereas no bioluminescence was evident with either form of strain Q614 (Table 1).

Taxonomy. The symbiont of Heterorhabditis sp. strain Q614 was a Gram-negative, facultatively anaerobic, rod-shaped bacterium with peritrichous flagella. The length of the cells was highly variable, ranging from 3 to $25 \mu \mathrm{m}$. The bacterium occurred in two colony forms. The primary form, isolated from infective-stage juveniles, produced convex, mucoid, pigmented colonies and adsorbed bromothymol blue from NBTA [NA with $0.0025 \%(w / v)$ bromothymol blue and $0.004 \%(\mathrm{w} / \mathrm{v})$ triphenyltetrazolium chloride; Akhurst (1980)] and neutral red from MacConkey agar. The secondary form, isolated from monoxenic in vitro cultures established with the nematode and primary-form symbiont, produced flattened, non-mucoid, nonpigmented colonies and adsorbed neither bromothymol blue nor neutral red. Both forms were pathogenic for Galleria larvae when injected intrahaemocoelically ( $>80 \%$ of Galleria larvae were killed after injection of 100 bacteria). Only the primary form showed lecithinase and antimicrobial activity and only the secondary form was positive for the test for phenylalanine deaminase and acidification of trehalose and of gluconate (API test only; both forms were negative when tested in peptone water with bromocresol purple as indicator). Both primary and secondary forms of strain Q614 shared the following biochemical features. They were positive for catalase, DNAase, phosphatase, urease, aesculin hydrolysis, casein hydrolysis, gelatin liquefaction and lipase (Tween 80 ), and utilized acetate, citrate, formate, fumarate, gluconate, 
Table 1. Bioluminescence in strains of X. luminescens measured in a scintillation counter

$\begin{array}{llcc}\text { Sample } & \text { Form } & \text { OD* } & \begin{array}{c}\text { Luminescence } \\ \text { (c.p.m. } \pm \text { SD) }\end{array} \\ \text { Water } & - & 0 & 38 \pm 16 \\ \text { Q614 } & \text { Primary } & 31 & 44 \pm 15 \\ & & 11 & 49 \pm 14 \\ & \text { Secondary } & 99 & 33 \pm 17 \\ \text { Cl } & & 11 & 32 \pm 18 \\ & \text { Primary } & 11 & >10^{6} \\ & & 1 & 36900 \pm 4 \\ & \text { Secondary } & 11 & 75700 \pm 4 \\ & & 1 & 309 \pm 6\end{array}$

lactate, L-malate and succinate in $O Y$ agar. They were both negative in tests for bioluminescence, oxidase, acetoin, indole, methyl red, arginine dihydrolase, lysine and ornithine decarboxylases, starch hydrolysis, $\mathrm{H}_{2} \mathrm{~S}$ production in triple sugar iron agar and tyrosinase, and did not utilize benzoate, malonate, oxalate or tartrate in OY agar.

Both forms produced acid from $\mathrm{N}$-acetylglucosamine, D-fructose, glucose, glycerol, inositol, maltose, mannose, ribose, salicin and D-xylose in the API system (phenol red indicator), although tests for acidification of glycerol, inositol, ribose, salicin and D-xylose in peptone water (bromocresol purple indicator) were negative. Both forms gave negative results for the acidification of melezitose in the API system but gave weak positive results in peptone water/bromocresol purple up to $3 \mathrm{~d}$, after which the $\mathrm{pH}$ rose. There was a weak acidification of galactose in the API system within $24-48 \mathrm{~h}$ but it was not detectable after $72 \mathrm{~h}$. There was no acidification of adonitol, amygdalin, D-arabinose, L-arabinose, D-arabitol, arbutin, cellobiose, dulcitol, D-fucose, L-fucose, $\beta$-gentiobiose, glycogen, inulin, 2-ketogluconate, 5-ketogluconate, lactose, D-lyxose, mannitol, melibiose, methyl $\alpha$-D-glucoside, methyl $\alpha$-D-mannoside, methyl $\beta$ xyloside, D-raffinose, rhamnose, saccharose, sorbitol, L-sorbose, starch, D-tagatose, D-turanose, xylitol or L-xylose in the API system; none of these sources was tested in peptone water.

Strain $\mathrm{Cl}$ differed from Q614 in being luminescent and in the acidification of amygdalin by both forms and of salicin by the secondary form. The secondary form of $\mathrm{Cl}$ produced yellow pigmentation.

Ultrastructure. Membranous inclusions were clearly visible in cells of both forms of strains Q614 and $\mathrm{Cl}$, although they were seen more commonly in cells of the luminescent strain $\mathrm{Cl}$ and occupied a greater proportion of the cell volume than in the non-luminescent Q614 strain (Figs 1 and 2). Batteries of membranes, similar to the lattice structures described by Boemare et al. (1983), were seen in both strains but only in a small proportion of the cells and were never very extensive (Fig. 3). Crystalline inclusions were also observed in both forms of strains Q614 and Cl (Figs 1 and 2).

\section{DISCUSSION}

With the exception of bioluminescence, the characteristics of the bacterial symbiont of Heterorhabditis sp. strain Q614 were very similar to those of $X$. luminescens strain $\mathrm{Cl}$ and of other $X$. luminescens isolates characterized by Akhurst (1983), Thomas \& Poinar (1983) and Grimont et al. (1984). Grimont et al. (1984) concluded from their DNA-DNA hybridization results that $X$. luminescens was a heterogeneous species and might represent several species. However, a numerical taxonomic study (Akhurst, 1982b) showed that this species could not be easily subdivided. It is suggested that strain Q614 be considered a non-luminescent biovar of $X$. luminescens.

Both the luminescent $(\mathrm{Cl})$ and non-luminescent (Q614) strains contained masses of membranous inclusions. The lattice structures reported by Boemare et al. (1983) were seen only rarely in both strains and may be a development from the membranous inclusions, but no intermediate structures were detected. The scarcity of the lattice structures in the luminous strain $\mathrm{Cl}$ indicates that they are unlikely to be essential for bioluminescence. 


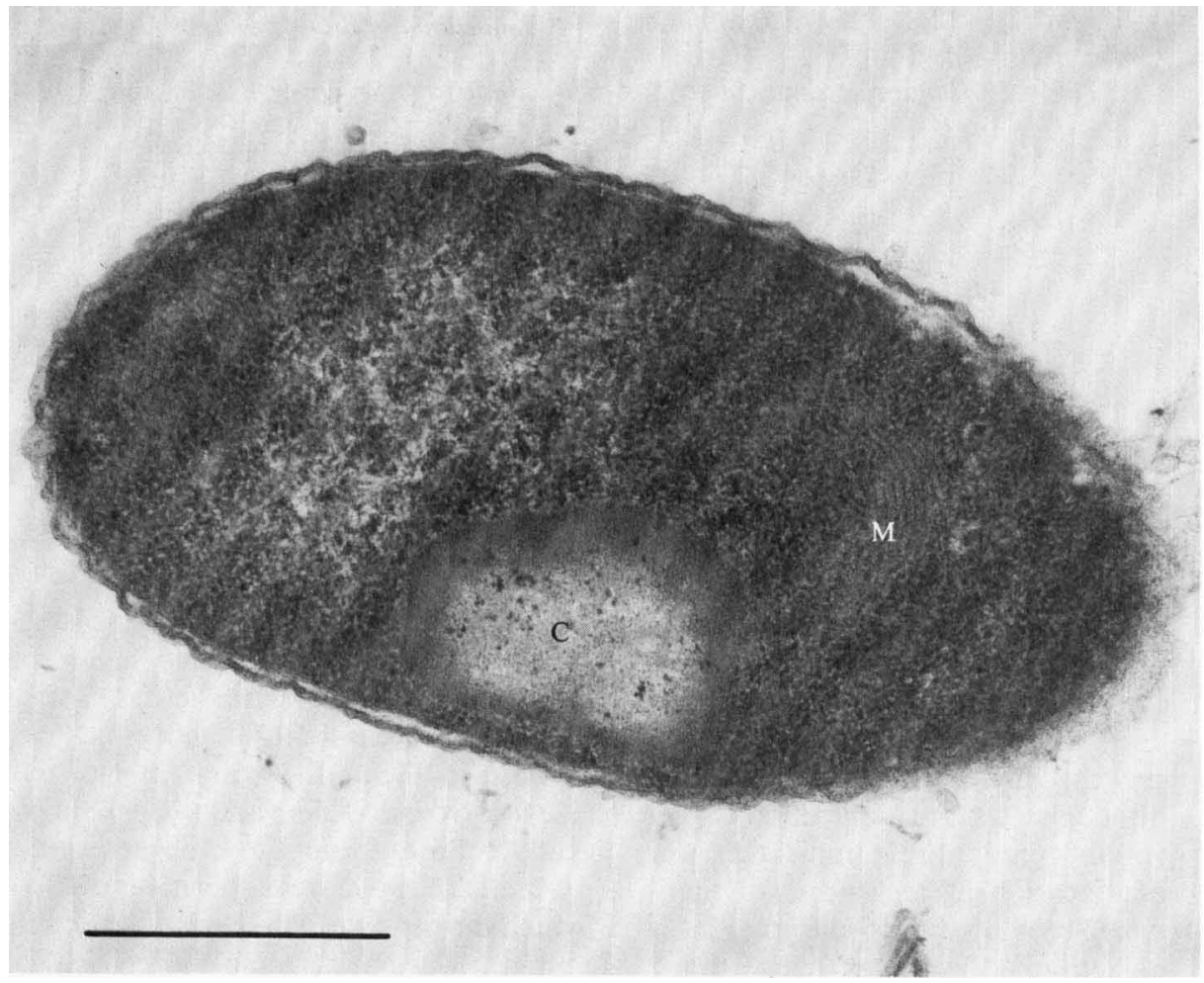

Fig. 1. Membranous (M) and crystalline (C) inclusions in a thin section of the non-luminescent strain Q614. Bar, $0.5 \mu \mathrm{m}$.

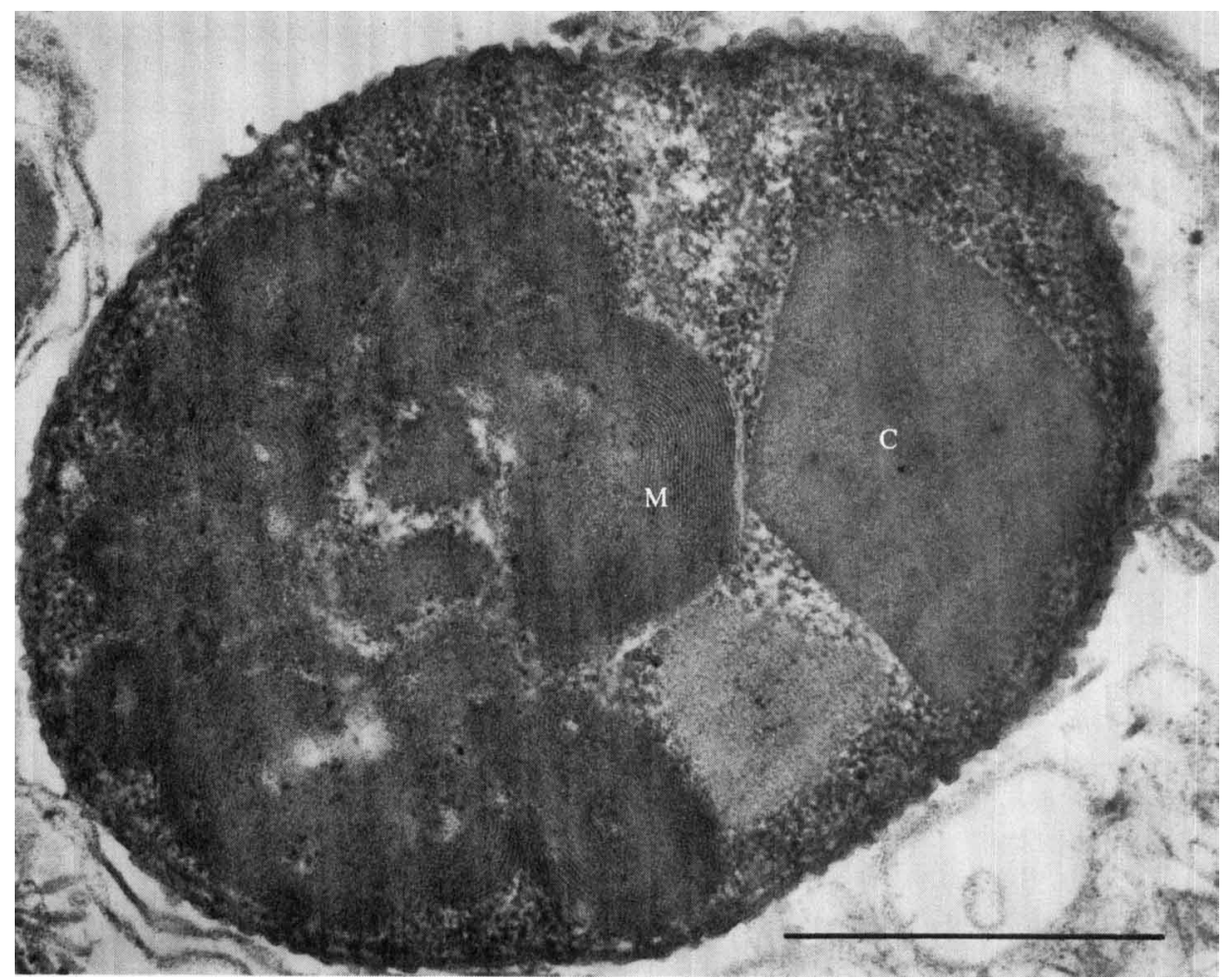

Fig. 2. Membranous (M) and crystalline (C) inclusions in a thin section of the luminescent strain $\mathrm{Cl}$. Bar, $0.5 \mu \mathrm{m}$. 


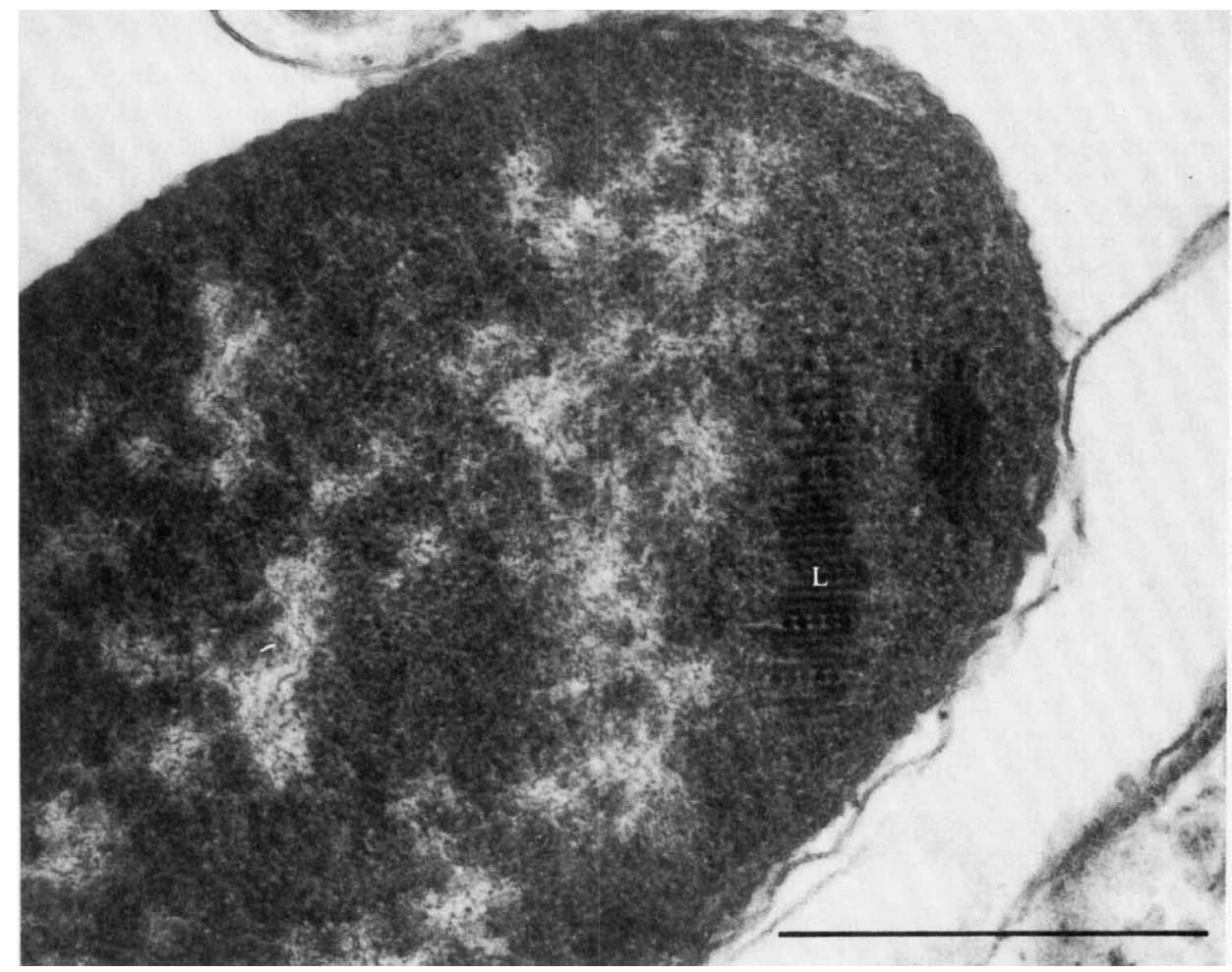

Fig. 3. Lattice structure (L) in a thin section of the luminescent strain $\mathrm{Cl}$. Bar, $0.5 \mu \mathrm{m}$.

The significance for bioluminescence of the membranous inclusions remains uncertain. Luminescence in other genera of bioluminescent bacteria may be affected at the gene or at the enzyme level (Hastings \& Nealson, 1981). Consequently, the occurrence of the membranous inclusions in the non-luminescent strain as well as in the luminescent strain does not necessarily indicate that they are not involved in bioluminescence.

The significance of bioluminescence in $X$. luminescens has not been determined. The nonluminescent biovar of $X$. luminescens may prove to be very useful for comparison with luminescent strains in determining the significance of bioluminescence in this species and its interaction with its nematode partners.

The authors wish to thank Institut National Recherche Agronomique and CSIRO for financial support enabling N.E. B. to work in Australia. We thank Mr C. D. Beaton for the electron micrographs and his comments on the ultrastructure. We also acknowledge the technical assistance of Messrs J. G. Moss, V. S. Patel and M. A. Stanfield.

\section{REFERENCES}

AKHURST, R. J. (1980). Morphological and functional dimorphism in Xenorhabdus spp., bacteria symbiotically associated with the insect pathogenic nematodes Neoaplectana and Heterorhabditis. Journal of General Microbiology 121, 303-309.

AKHURST, R. J. (1982a). Antibiotic activity of Xenorhabdus spp., bacteria symbiotically associated with insect pathogenic nematodes of the families Heterorhabditidae and Steinernematidae. Journal of General Microbiology 128, 3061-3066.

AKHURST, R. J. (1982b). Bacterial symbionts of insect pathogenic nematodes. $\mathrm{PhD}$ thesis, University of Tasmania, Australia.

AkHURst, R. J. (1983). Taxonomic study of Xenorhab$d u s$, a genus of bacteria symbiotically associated with insect pathogenic nematodes. International Journal of Systematic Bacteriology 33, 38-45.

BEDDING, R. A. (1984). Large scale production, storage and transport of the insect-parasitic nematodes Neoaplectana spp. and Heterorhabditis spp. Annals of Applied Biology 104, 117-120.

BEDdING, R. A. \& AkHuRst, R. J. (1975). A simple 
technique for the detection of insect parasitic rhabditid nematodes in soil. Nematologica 21, 109110.

Boemare, N., Louis, C. \& Kuhl, G. (1983). Etude ultrastructurale des cristaux chez Xenorhabdus spp., bactéries inféodées aux nématodes entomophages Steinernematidae et Heterorhabditidae. Comptes rendus des séances de la Société de biologie 177, 107115.

DYE, D. W. (1968). A taxonomic study of the genus Erwinia. I. The 'amylovora' group. New Zealand Journal of Science 11, 590-607.

FrazIER, W. C. (1926). A method for the detection of changes in gelatin due to bacteria. Journal of Infectious Diseases 39, 302.

GöTz, P., Boman, A. \& Boman, H. G. (1981). Interactions between insect immunity and an insectpathogenic nematode with symbiotic bacteria. Proceedings of the Royal Society B212, 33-35.

Grimont, P. A. D., Steigerwalt, A. G., Boemare, N., Hickman-Brenner, F. W., Deval, C., GriMONT, F. \& BRENNER, D. J. (1984). Deoxyribonucleic acid relatedness and phenotypic study of the genus Xenorhabdus. International Journal of Systematic Bacteriology 34, 378-388.

Hastings, W. J. \& Nealson, K. H. (1981). The symbiotic luminous bacteria. In The Prokaryotes, vol. II, pp. 1333-1345. Edited by M. Starr, H. Stolp,
M. G. Trüper, A. Balows \& H. G. Schlegel. Berlin: Springer-Verlag.

KhAN, A. \& BROOKs, W. M. (1977). A chromogenic bioluminescent bacterium associated with the entomophilic nematode Chromonema heliothidis. Journal of Invertebrate Pathology 29, 253-261.

PoINAR, G. O. \& Thomas, G. M. (1966). Significance of Achromobacter nematophilus Poinar and Thomas (Achromobacteraceae: Eubacteriales) in the development of the nematode, DD136 (Neoaplectana sp.: Steinernematidae). Parasitology 56, 385-390.

Poinar, G. O., Thomas, G. M. \& Hess, R. (1977). Characteristics of the specific bacterium associated with Heterorhabditis bacteriophora (Heterorhabditidae: Rhabditida). Nematologica 23, 97-102.

REYNOLDS, E. S. (1963). The use of the lead citrate at high $\mathrm{pH}$ as an electron opaque stain in electron microscopy. Journal of Cell Biology 17, 208-212.

SiERRA, G. (1957). A simple method for the detection of lipolytic activity of micro-organisms and some observations on the influence of the contact between cells and fatty substances. Antonie van Leeuwenhoek 23, 15-22.

Thomas, G. M. \& Poinar, G. O. (1983). Amended description of the genus Xenorhabdus Thomas and Poinar. International Journal of Systematic Bacteriology 33, 878-879. 